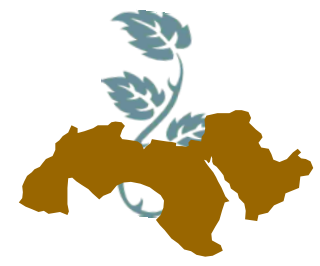

Arab Univ.

J. Agric. Sci., Ain Shams Univ., Cairo, 24(1), 127-138, 2016

\title{
SPRAYING SOME ORGANIC COMPOUNDS ON KING RUBY GRAPEVINES FOR POWDERY MILDEW RESISTANCE
}

\author{
Ansam S. Abd El-Rahman ${ }^{1}$; Magda N. Mohamed ${ }^{1}$ and Howida A. Metwaly ${ }^{2}$ \\ 1- Viticulture Res. Dept., Hort. Res. Instit., Agric. Res. Center, Giza, Egypt \\ 2- Central Lab. of Organic Agriculture, Agric. Res. Center, Giza, Egypt \\ E-mail: Magdanagib2101@yahoo.com
}

Keywords: Grapevine, Uncinula necator, T. harzianum, T. viride, Bacillus subtilis and blight stop

\section{ABSTRACT}

This investigation was conducted for two successive seasons (2013 and 2014) in a private vineyard located at $64 \mathrm{Km}$ of Cairo-Alexandria desert road to study the possibility of using organic products to reduce powdery mildew, which it is reflect in reducing yield and fruit quality of King Ruby grapevines. The chosen vines were tenyears-old, grown in a sandy loam soil, spaced at $1.5 \times 3.0$ meters apart and irrigated by the drip irrigation system, trained to bilateral cordon with spur pruning, and trellised by the " $Y$ " shape system. The vines were pruned during the last week of January with bud load of (60buds/vine). Application of different biocontrol agents Trichoderma harziamum, Trichoderma viride, Bacillus subtilis as well as blight stop a commercial biocide which contains different isolates of Trichoderma forms in Arabic gum and potassium soap) were obtained kindly from central lab. of organic agriculture, ARC. Giza, in an attempt reduces powdery mildew of the plants.

The results showed that all vital bioagents treatments significantly were reduced the powdery mildew disease compared with micron sulphur and control in both season. However, spraying mixture of Trichoderma harziamum + Trichoderma viride and blight stop gave the least disease incidence and severity which it is reflect to increase yield, achieve the best physical characteristics of bunches as well as improving the physical and chemical properties of berries.

\section{INTRODUCTION}

Grapevine (Vitisvinifera L.) is one of the most important fruits grown in Egypt. Grapevine is subjected to the infection with powdery mildew caused by Uncinu lanecator Schwe in Burrill. teleomorph of Oidiumtuckeri Berk. Recently, renamed Erysiphenecator Schw. and placed into the section Uncinula of the genus (Braun and Takamatsu, 2000). Powdery mildew is a worldwide economically important fungal disease in the grapevine farms and the most enduring and widespread problem. It costs million dollars annually to vine growers, due to croplosses and an intensive usage of fungicides for its control (Rumbolz et al 2000; Miazzi et al 2003; Hajjeh et al 2005; Péros et al 2005 and Crisp et al 2006). The damage caused by the pathogen, $U$. necator, has been noticed from the studies of the disease on cultivars of the European grape species (Calonnec et al 2004). In Egypt, powdery mildew was found on different varieties of grapevine causing considerable losses in grape production (David et al 2001; Gadoury et al 2001 and Saleh et al 2007). Powdery mildew can result in reducing vine growth, yield, fruit quality and winter hardness. Uncontrolled, the disease can be devastating on susceptible varieties under the proper environmental conditions. However, infection caused by this fungus is developed in high humidity conditions but not by free water (Ellis et al 2008). In addition, the release of as cospores has always been associated with rainy periods where cumulative rainfall ranged between 2 and $58.5 \mathrm{~mm}$. Therefore, rain is necessary for ascospore release that is a primary in oculasource (Jailloux et al 1999). E. necatorhas been reported 
to overwinter as mycelium or conidia in dormant buds and/or as cleistothecia on infected tissues, on the bark of vines or in the soil (Delye et al 1997; Miazzi et al 2003 and Cortesi et al 2005).

Several antagonistic microorganisms were recorded to be promising candidate and effective for controlling wide range of plant pathogens including these bioagents species of Trichoderma (Chet et al 1997) and Bacillus spp. (Sharifi and Ramezani 2003). The use of synthetic chemicals to control plant diseases is to be coming more restricted. The added costs for controlling diseases make losses even more important economically. Development of resistance in the pathogens, residual effects and environmental pollution which led to an increase of health hazards due to their phytotoxic residual and pollution effects along of the cost of controlling diseases are problems associated with use of these chemicals. Recently, search for substances alternative have been initiated. Therefore using some other means of disease control instead of agrochemical is strongly encourage.

Biological control of plant diseases using microorganisms is a very promising alternative to the extended use of fungicides. The biological control of plant pathogenic fungi has received considerable attention as an alternative strategy (EI-Rafai Ilham et al 2003). Among the biological control agents Trichoderma spp. is the most promising and effective biocontrol agent. Trichoderma spp. as antagonist controlling wide range of microbes and their mechanism of mycoparasitism is much more complex, involves nutrient competition, hyperparasitism, antibiosis, space and cell wall degrading enzymes. Trichoderma harzianum Rifai is a cosmopolitan species that might be found in the ground. Trichoderma harzianumcan be considered as identical biocontrol agent for its ideal characteristic. This antagonist is very easy to be isolate and grows rapidly on any organic staff. $T$. harzianum act through different mode of actions i.e. mycoparasitism (Abd El-Moity \& Shatla, 1981; Benhamoud \& Chet, 1993 and Abada, 2002), production of antifungal (Hayes 1992 and Robinson et al 2009), also it owns enzyme system causes destruction for the pathogens (Abd El-Moity, 1981; Bolar et al 2000 and Ziedan et al 2005). In addition to these modes of action Trichoderma spp. also act as inducer for resistance in treated plants against certain pathogen organs (Harman 2006). It is also clear that it can grow within wide range of temperature and other environmental conditions (Singh et al 2010). Use of Trichoderma spp. as a tool in the biological control of many plant diseases has been a subject of many workers (Osman et al 2001 and Abd El-Moity et al 2003).

Mixing antagonists with each other's (Trichoderma harzianum Rifai and Trichoderma viride Harz.) might be lead to antagonistic effect consequently decrease efficacy of treatment (Robinson et al 2009) or lead to synergistic effect and increase the efficacy (Latha et al 2009). This increase or decrease is due to harmony and compatibility factors between bioagents.

Bacillus subtilis is widely spread in nature. It might be used for suppressing plant diseases caused by bacteria and fungi. This bacterium suppresses harmful microorganisms through the competition for food and directly populating them. It is not toxic for humans and environment (EPA, 2009). B. subtilis Cohn is antagonistic to plant pathogenic fungi and bacteria. Bacillus spp. produced at least 66 different antibiotic compounds (Ferreira et al 1991). The antagonistic effect of $B$. subtilis against many pathogenic fungi was examined in vitro and in vivo (Abd El-Moity et al 2003 and Hussein et al 2007). The antagonistic mechanism of these bacteria for plant pathogens involved antibiosis competition for nutrients or space, enhancement of root and plant development, induction of plant resistance, solubilization and sequestration of inorganic nutrients and/or inactivation of the pathogen enzymes (Intana et al 2008).

Sulphur can be applied as a spray or dust. Dusting sulphur is popular in the USA but used rarely in Australia, even though it is considered an effective product (Possingham, 2002). Sulphur works by killing the spores of powdery mildew, thus protecting the vines from new infections. It does not kill the fungus itself. The best use of sulphur therefore, is to prevent vines from becoming infected, rather than to suppress infections once they have developed. Existing mature fungal colonies will begin producing more spores as soon as a week after a sulphur spray is applied. Sulphur is a popular fungicide because it is relatively cheap and provides good results under less than ideal application conditions. The latter point is due to the fact that under suitable conditions (temperatures $25^{\circ} \mathrm{C}$ to $30^{\circ} \mathrm{C}$ ), sulphur becomes volatile, and to a degree it 'fumigates' the foliage and bunches, including areas that were not actually contacted by the spray or dust.

The present work was designed to find out effective, nontoxic, in harmony with organic production rules. Products used to control diseases which can replace toxic chemical substances now in 
grapevine field systems. These safe products will help in protecting biological balance, keep our environment clean, in addition it will help in organic production. Organic products in markets have special high prices, so this work will also improve the income farmers and consequently lead to increase organic products which will lead to increase in the national income .In this work, different single bio agents or mixture of bio agents with others were tested under Egyptian conditions. goal of this study is the use of vital bio agents treatments to control powdery mildew, which it is reflect to increase vine growth, yield and fruit quality of King Ruby grapevines compare with chemical treatment (micron sulphur) and untreated vines (control).

\section{MATERIAL AND METHODS}

This investigation was conducted for two successive seasons (2013and2014) in a private vineyard located at $64 \mathrm{Km}$ of CairoAlexandria desert road to study the possibility of using organic products to reduce using powdery mildew, which it is reflect to evaluate vine growth, yield and fruit quality of King Ruby grapevines. The chosen vines were tenyears-old, grown in a sandy loam soil, spaced at $1.5 \times 3.0$ meters apart and irrigated using drip irrigation system, trained to bilateral cordon with spur pruning, and trellised by the "Y" shape system. The vines were pruned during the last week of January with bud load of $(60$ buds/vine) in both seasons according to Fawzi et al (1984).

All vines received the same agricultural practices already applied in the vineyard. Different bio control agents Trichoderma harzianum, Trichoderma viride, Bacillus subtilis and blight stop as commercial biocide were kindly obtained from Central Lab. of Organic Agriculture, ARC. Giza. Trichoderma harzianumand Trichoderma viride were grown in liquid fermentation medium (GFM) developed by Brain and Hemming (1945) for 11 days under complete darkness condition, at $25^{\circ} \mathrm{C}$. $B$. subtilis was grown on nutrient glucose broth (NGB) prepared by Dowson (1957) for 2 days, at $25^{\circ} \mathrm{C}$. Mixture of $T$. harzianumand $T$. viride were mixed at the rate of $1: 1$. Biocontrol agents or mixture of bioagents were prepared in form consists of bioagent plus water just to modify the number of propagules/each $\mathrm{ml}$ to be contain $30 \times 10^{6} \mathrm{per}$ each $\mathrm{ml}$ of the preparation in (Abd El-Moity and Shatla, 1981). Adjusted preparations and blight stop as commercial biocide were diluted to be at the rate of 1: 100L. Blight stop contains different isolates of Trichoderma with other formula consist of adjusted culture plus $5 \%$ Arabic gum and $0.5 \%$ potassium soap to increase adhesive capacity and improve distribution of bio agents on the surface of treated plants.

The application rate for wet table sulphur were diluted adjusted preparations were used to spray grape leaves. Recent local research (Emmett et al 2003a \& 2003b) has shown that management of powdery mildew can be improved through the use of the newer, higher label rate of sulphur, i.e. $600 \mathrm{~g} / 100 \mathrm{~L}$, when applied at the volumes required to achieve thorough coverage of the vine foliage. This rate is registered for some sulphur products and growers can choose between the two application rates depending upon the disease pressure in their vineyard.

Each four vines acted as a replicate and each three replicates were treated by one of the following treatments where six treatments were applied as follows:

1. Bacillus subtilis

2. Trichoderma harziamum

3. Trichoderma viride

4. Mixture of Trichoderma harziamum + Trichoderma viride

5. Blight stop with

6. Micron sulphur.

7. Untreated vines (control)

The following plant parameters were adopted to evaluate the tested treatments

\section{Disease assessment}

For powdery mildew assessment, the evaluations on leaves were carried out 15 days after the last application.

$\%$ Disease incidence (DI) was determined according to the following formula:

DI \% $=$ (Number of infected leaves / Total No studied leaves $X 100)$.

The percentage of disease severity for each particular treatment was calculated using the following formula:

DS \% $=($ Sum $(n X v) / 11 \mathrm{~N} X 100$

Where: $n=$ number of plants in every grade

$\mathrm{v}=$ Numerical grade

$\mathrm{N}$ =total number of examined leaves

$11=$ Maximum disease grade

Leaf infection was evaluated based on the scale on ten leaves for each in fection replicate was evaluated according to Horsfall and Barrat 
(1945). Five trees were estimated for disease symptoms from each replicate, leaves were selected randomly from each treatment and classified to score on a (12) leaves rating scale, representing a percentage of surface infected area.

Representative random samples of 6 bunches/vine were harvested at maturity when total soluble solids (TSS) reached about $16-17 \%$ according to Tourky et al (1995).

The following plant parameters were determined

\section{Yield and physical characteristics of bunch}

Yield/vine $(\mathrm{kg})$ was determined as number of bunches/vine $X$ average bunch weight $(\mathrm{g})$. Also, bunch length and width $(\mathrm{cm})$ were determined.

\section{Physical characteristics of berries}

Average berry weight $(\mathrm{g})$, berry size $\left(\mathrm{cm}^{3}\right)$ and berry dimensions (length and diameter) $(\mathrm{cm})$ were determined.

\section{Chemical characteristics of berries}

Total soluble solids in berry juice (TSS \%) by hand refractometer and total titratable acidity as tartaric acid (\%) (A.O.A.C. 1985). Hence TSS /acid ratio and total anthocyanin of the berry skin (mg/100g fresh weight) were calculated according to Husia et al (1965).

\section{Statistical analysis}

The complete randomized block design was adopted for the experiment. The statistical analysis of the present data was carried out according to Snedecor and Cochran (1980). Averages were compared using the new LSD values at $5 \%$ level.

\section{RESULTS AND DISCUSSION}

\section{Disease incidence}

The efficacies of test bio control agents as well as commercial biocide under natural conditions were determined in two seasons 2013 and 2014 . Results in Table (1) show that all bio agents treatments vital significantly reduced the disease incidence of powdery mildew compared with micron sulphur and control in both seasons. However, significant differences were found among the bio agents vital treatments. Data also showed that, mixture of $T$. harzianum and $T$. viride reveals the first rank when compared with the other bioagents in reducing disease incidence percentage at first season (2013) which recorded 10\%. Trichoderma spp. long time have been known for their abilities in controlling plant pathogenic fungi mechanisms primarily have include direct effects upon target fungi via competition, mycoparasitism and antibiosis (Abd El-Moity, 1981 and Harman, 2006). In consequence these fungi have been shown to directly increase plant growth (Chang et al 1986).On the other hand, blight stop which forms in Arabic gum and $0.5 \%$ potassium soap recorded the highest effect (10.5\%) at the second season (2014) followed by the mixture of both Trichoderma spp. forms in water. Obtained results also showed that using the antagonist as suspension in Arabic gum plus potassium soap gave better results compare with using the same antagonist as water suspension. This is due to Arabic gum and potassium soap create a slimy thin film surround treated roots and improve establishment of antagonistic propagules on the treated surfaces. Many investigators reported efficacy of bio control agents in plant protection against different air borne pathogens. Some investigators explain this protection effect as antibiosis action occurred in court of infection (Matei and Matei, 2008). Some other investigators reported changes in plant physiology and chemical components in plants treated with these bio agents (Hafez et al 2012). where the other act through production of antifungal substances such as Endo chitinase, Beta -glucosidase, alpha -1,3-glucanase (Monteiro et al 2011) and trichodermin (Balode 2010) other isolates compete for space or nutrients. Mixing different isolates increase the scope of mode of action consequently increase efficacy of the treatment.

\section{Disease severity}

As shown data in Table (1) clear that the disease severity of powdery mildew was significantly decreased by all bio agents treatments vital in both seasons. Blight stop records the highest effect in the first season (2013) being (22.33\%). B. subtilis was the superior bio agents resulting a decrease in the disease severity at second season (2014) being $(17.15 \%)$. This might be due to that bacteria produced more antibiotic (bacteriosin and subtilisin) which act as inhibitors to pathogenic fungi (Ferreira et al 1991; Aska \& Shoda 1996 as well as Abd El-MoneimMaisa, et al 2006). B. subtilis 
might also grows very fast and occupied the court of infection and consumes all available nutrients while prevent pathogens to invade the plant. Application of $B$. subtilis was the most effective if compared with the other treatments. This can be explained on the light of fact that $B$. subtilis grow very fast and occupied the court of infection and compete for spaces and nutrients so prevent pathogens to invade plants (Wolk and Sorkar 1994). In addition $B$. subtilis produces some growth regulators that might increase all growth parameters compared with control treatment (Asaka \& Shoda 1996 and Grosch \& Grote 1998).

Table 1. Disease incidence and severity of powdery mildew on King Ruby grapevines at seasons 2013 and2014 as affected by some bioagent treatments

\begin{tabular}{|c|c|c|c|c|}
\hline \multirow[b]{2}{*}{ Treatments } & \multicolumn{2}{|c|}{ Season 2013} & \multicolumn{2}{|c|}{ Season 2014} \\
\hline & $\begin{array}{c}\% \\
\text { Disease } \\
\text { incidence }\end{array}$ & $\begin{array}{c}\% \\
\text { Disease } \\
\text { severity }\end{array}$ & $\begin{array}{c}\% \\
\text { Disease } \\
\text { incidence }\end{array}$ & $\begin{array}{c}\% \\
\text { Disease } \\
\text { severity }\end{array}$ \\
\hline $\begin{array}{l}\text { Bacillus } \\
\text { subtilis }\end{array}$ & 12.33 & 26.69 & 16.7 & 17.15 \\
\hline $\begin{array}{c}\text { T.harzianum } \\
\text { (T1) }\end{array}$ & 15 & 32.59 & 23.3 & 26.69 \\
\hline T. viride (T2) & 16.67 & 33.26 & 20 & 24.47 \\
\hline $\begin{array}{l}\text { Mixture of } \\
\text { (T1 and T2 ) }\end{array}$ & 10 & 28.92 & 13.3 & 31.11 \\
\hline Blight stop & 11.67 & 22.33 & 10.7 & 20 \\
\hline Micronsulphur & 17.67 & 36.67 & 25 & 34.33 \\
\hline Control & 26.7 & 41.24 & 33.33 & 49.66 \\
\hline L.S.D at 0.05 & 1.8 & 1.3 & 5.7 & 5.3 \\
\hline
\end{tabular}

\section{Yield and physical characteristics of} bunch

The results presented in Table (2) reveal that yield and physical characteristics of bunch i.e. average of bunch weight, bunch length and bunch width were significantly affected by the conducted treatments in both seasons. Blight stop as commercial biocide indicate the highest significant yield value increased in both seasons (30.8 and 29.6 $\mathrm{kg}$ ). Blight stop also increased bunch weight at first season $(751.2 \mathrm{~g})$ while spraying with $B$. subtiliswas the most effective at the second one $(778.6 \mathrm{~g})$. Average bunch length increased when treated with blight stop at the first season $(32.8 \mathrm{~cm})$. While mixture of Trichoderma harziamum + Trichoderma viride $(36.3 \mathrm{~cm})$. Average bunch width increased by spraying with mixture of Trichoderma harziamum +
Trichoderma viride resulted at first season $(18.7 \mathrm{~cm})$. These synergistic effects are due to the dual effect of bio agent which produce growth regulators (Karlidag et al 2012) in addition to their effect as resistant inducer (Constantinescu et al 2009). On the other hand, application of $B$. subtilis recorded the highest values ones at the second season $(19.1 \mathrm{~cm})$ compared with micron sulphur and control. These effects might be ascribed to the positive action of compounds application in reducing of disease incidence as well as improving fruit characteristics. Some of these applied compounds contain nutrient elements that have a positive action for improving the yield and quality of grapes (Ahmed et al 1991). On the other hand, using of these compounds for controlling powdery mildew were accompanied with protecting bunches from fruit rots which reflected in decreasing fruit dropping and succeeded in gaining heaviest bunches and high yield. This good system increase photosynthesis consequently amount of sugars and lead eventually to good yield. This increase in yield is due to vigorty of healthy plants, in addition to growth regulators are produced by Trichoderma spp. and $B$. subtilis which improve photosynthesis metabolism in treated plants (Hernandez et al 2011). This improvement led to increase in yield and dry matter.

\section{Physical characteristics of berries}

Results in Table (3) show that all vital activities significantly improved physical characteristics of berries i.e. average berry weight, berry size, berry length and berry diameter compared with micron sulphur treatment and control in both seasons. Significant differences were found among the organic material vital activities as according to Geza et al (1984). Spraying with Trichoderma harziamum + Trichoderma viride and blight stop gave the highest values for these parameters followed in a descending order by spraying with Bacillus subtilis, while, micron sulphur and control recorded the least values in both seasons. This high potentiality in antagonism might be due to the compatible and synergistic relation between Trichoderma isolates which acts through different mechanisms including mycoparasitism (Benhamoud and Chet 1993 and Harman 2006), and production of antifungal substances (Hayes, 1992). Trichoderma spp. might also act through production of destructive enzymes i.e.chitenase (Bolar et al 2000). Tronsmo et al (1993) mentioned that, T. harzianum isolates produce chitinase and 1,3 gluconase enzymes which 
Table 2. Yield and physical characteristics of bunch on King Ruby grapes at seasons 2013 and 2014 as affected by different bio agent treatments

\begin{tabular}{|c|c|c|c|c|c|c|c|c|}
\hline \multirow{2}{*}{ Treatments } & \multicolumn{2}{|c|}{$\begin{array}{c}\text { Yield/vine } \\
\text { (kg) }\end{array}$} & \multicolumn{2}{c|}{$\begin{array}{c}\text { Average bunch } \\
\text { weight } \\
\text { (g) }\end{array}$} & \multicolumn{2}{c|}{$\begin{array}{c}\text { Average } \\
\text { bunch length } \\
\text { (cm) }\end{array}$} & \multicolumn{2}{c|}{$\begin{array}{c}\text { Average bunch } \\
\text { width } \\
\text { (cm) }\end{array}$} \\
\cline { 2 - 9 } & $\mathbf{2 0 1 3}$ & $\mathbf{2 0 1 4}$ & $\mathbf{2 0 1 3}$ & $\mathbf{2 0 1 4}$ & $\mathbf{2 0 1 3}$ & $\mathbf{2 0 1 4}$ & $\mathbf{2 0 1 3}$ & $\mathbf{2 0 1 4}$ \\
\hline Bacillus subtilis & 20.4 & 18.3 & 733.9 & 778.6 & 32.3 & 35.7 & 18.2 & 19.1 \\
T. harzianum (T1) & 19.3 & 18.1 & 726.7 & 751.8 & 31.9 & 35.4 & 17.9 & 18.4 \\
T. viride (T2) & 19.2 & 17.2 & 705.1 & 728.7 & 31.7 & 35.1 & 17.7 & 18.1 \\
Mixture of (T1+T2) & 21.6 & 19.6 & 746.5 & 773.3 & 32.6 & 36.3 & 18.7 & 18.9 \\
Blight stop & 21.8 & 20.6 & 751.2 & 758.1 & 32.8 & 36.2 & 18.4 & 18.6 \\
Micron sulphur & 18.2 & 16.3 & 663.3 & 684.5 & 31.1 & 34.3 & 17.4 & 17.7 \\
Control & 17.7 & 15.9 & 647.4 & 669.2 & 30.7 & 33.8 & 17.1 & 17.5 \\
\hline L.S.D at $\mathbf{0 . 0 5}$ & $\mathbf{1 . 5}$ & $\mathbf{1 . 7}$ & $\mathbf{1 6 . 3}$ & $\mathbf{1 7 . 1}$ & $\mathbf{0 . 5}$ & $\mathbf{0 . 6}$ & $\mathbf{0 . 4}$ & $\mathbf{0 . 3}$ \\
\hline
\end{tabular}

Table 3. Physical characteristics of berries on King Ruby grapes at seasons 2013 and 2014 as affected by different bioagent treatments

\begin{tabular}{|c|c|c|c|c|c|c|c|c|}
\hline \multirow{2}{*}{ Treatments } & \multicolumn{2}{|c|}{$\begin{array}{c}\text { Average berry } \\
\text { weight } \\
\text { (g) }\end{array}$} & \multicolumn{2}{|c|}{$\begin{array}{c}\text { Average berry } \\
\text { size } \\
\text { (cm3) }\end{array}$} & \multicolumn{2}{c|}{$\begin{array}{c}\text { Average berry } \\
\text { length } \\
\text { (cm) }\end{array}$} & $\begin{array}{c}\text { Average berry } \\
\text { diameter } \\
\text { (cm) }\end{array}$ \\
\cline { 2 - 9 } & $\mathbf{2 0 1 3}$ & $\mathbf{2 0 1 4}$ & $\mathbf{2 0 1 3}$ & $\mathbf{2 0 1 4}$ & $\mathbf{2 0 1 3}$ & $\mathbf{2 0 1 4}$ & $\mathbf{2 0 1 3}$ & $\mathbf{2 0 1 4}$ \\
\hline Bacillus subtilis & 3.01 & 3.18 & 2.99 & 3.01 & 1.70 & 1.74 & 1.58 & 1.63 \\
T. harzianum (T1) & 2.93 & 3.08 & 2.75 & 2.89 & 1.68 & 1.71 & 1.64 & 1.59 \\
T. viride (T2) & 2.85 & 3.01 & 2.71 & 3.14 & 1.67 & 1.69 & 1.55 & 1.58 \\
Mixture of (T1+T2) & 3.09 & 3.32 & 2.94 & 3.08 & 1.72 & 1.79 & 1.61 & 1.65 \\
Blight stop & 3.17 & 3.27 & 2.85 & 2.85 & 1.75 & 1.77 & 1.57 & 1.67 \\
Micron sulphur & 2.79 & 2.96 & 2.63 & 2.79 & 1.64 & 1.65 & 1.52 & 1.54 \\
Control & 2.77 & 2.93 & 2.59 & 2.76 & 1.61 & 1.61 & 1.50 & 1.51 \\
\hline L.S.D at $\mathbf{0 . 0 5}$ & $\mathbf{0 . 1 3}$ & $\mathbf{0 . 1 1}$ & $\mathbf{0 . 1 2}$ & $\mathbf{0 . 0 9}$ & $\mathbf{0 . 0 5}$ & $\mathbf{0 . 0 4}$ & $\mathbf{0 . 0 5}$ & $\mathbf{0 . 0 3}$ \\
\hline
\end{tabular}

are responsible for dissolving cell wall of the pathogenic fungi, then it can grow and consume the inner contents of the pathogen. The effect of biocontrol agent might due to production of antifungal as virdin, gliotoxine and bassellin (Sivan and Chet 1992 and Tourky et al 1995). Mixing bioagents with each other's might be lead to antagonistic effect consequently decrease treatment efficacy (Robinson et al 2009) or lead to synergistic effect and increase the efficacy. This might be due to compatible relation between mixture of Trichoderma isolates, leading to synergistic effect between them and improving all vegetative growth and yield. Action of $B$. subtilis is due to its growth very fast and occupied the court of infection in addition to production number of antibiotics (Ryder et al 1999). Treatment with $B$. subtilis proved to be the most effective one compared to other ones. This might be due to that $B$. subtilis grows very fast and occupies the court of infection and consumes all available nutrients. These actions prevent pathogen spores to germinate and reach susceptible tissues. Also its effect might be due to competition for spaces or nutrients (Wolk and Sorkar, 1994). In addition $B$. subtilis produces some growth regulators that increased all plant growth parameters compared with control treatment (Asaka \& Shoda 1996; Sankar \& Jeyarajan 1996 and Grosch \& Grote 1998). Disease reduction led to increase in fruit yield of treated plants. This increase in yield is due to vigorty of healthy plants, in addition to growth regulators produced by Trichoderma spp. and/or $B$. subtilis which improve photosynthesis metabolism in treated plants (Govindappa et al 2011). This improvement led to an increase in yield and dry matter. Bioagents do not only affect the 
outer treated plants but also affect inner plant metabolism leading to changes in plant component (Hafez et al 2012).

\section{Chemical characteristics of berries}

As shown data in Table (4) it is apparent that all berry chemical properties i.e. total soluble solids, titratable acidity, TSS/acid ratio and anthocyanin was significantly improved by all bioagents treatments in both seasons while the lowest values of acidity were obtained by spraying with blight stop followed by spraying with mixture of Trichoderma harziamum + Trichoderma viride. Micron sulphur treatment and control recorded the least values of total soluble solids, TSS/acid ratio and anthocyanin and the highest values of acidity in both seasons. These synergistic effects might be due to the dual effect of bioagent which produce growth regulators in addition to their effect as resistant inducer (Constantinescu et al 2009). Bioagents do not only affect outer surface plant but also affect plant metabolism leading to changes in plant components (Hafez et al 2012). Data obtained in Table (4) also indicated that all treatments led to an increase in the all tested parameters of fruits in compared with micron sulphur and control treatments. Obtained data also reveal that blight stop was the most effective showing the highest ratios in total soluble solids, TSS/acid ratio and anthocyanin. The other treatments varied in their effects on different parameters. Blight stop show the least values in titratable acidity of successive examined seasons as well as mixture of Trichoderma harziamum + Trichoderma viride of the first one. This might be due to their effect on powdery mildew pathogen and have a profound effect on crop health (Kloepper et al 2004).
Tronsmo et al (1993) mentioned that, T. harzianum isolates produce chitinase and 1,3 gluconase enzymes which are responsible fordissolving cell wall of the pathogenic fungi, then grow and consume its inner contents causing destruction of the pathogen. Fruit quality must be considered when any treatments take place on harvested fruit. In this experiment samples of grape fruits obtained from different treatments were analyzed to be sure that the quality parameters did not disturbed. Obtained data showed that all quality parameters (TSS, TSS/acid ratio and anthocyanin) were increased when any of used treatment was applied while decrease titratable acidity in compared with micron sulphur and control. Total soluble solids and anthocyanin was significantly increased. This increase might be due to the healthy and vigorty of treated plants. This vigorty improve photosynthesis and other biological activity in plant physiology consequently increases TSS and anthocyanin (Fawzi et al 2010).

Economical justification of the contribution of different vital bioagent treatments in raising vine productivity by reduced the powdery mildew disease compared with micron sulphur and control

It can be shown from the data presented in Table (5), that spraying mixture of Trichoderma harziamum + Trichoderma viride or blight stop gave the maximum net profit compared with micron sulphur and control in both seasons. In spite of the high costs of all vital bioagents treatments over control. Hence, it can be anticipated that the added cost of establishment will be offset by an increase in vine productivity.

Table 4. Chemical characteristics of berries on King Ruby grapes at 2013 and 2014 seasons affected by different bioagent treatments

\begin{tabular}{|c|c|c|c|c|c|c|c|c|}
\hline \multirow{2}{*}{ Treatments } & \multicolumn{2}{|c|}{$\begin{array}{c}\text { TSS } \\
\text { (\%) }\end{array}$} & \multicolumn{2}{c|}{$\begin{array}{c}\text { Acidity } \\
\text { (\%) }\end{array}$} & \multicolumn{2}{c|}{$\begin{array}{c}\text { TSS/acid } \\
\text { ratio }\end{array}$} & \multicolumn{2}{c|}{$\begin{array}{c}\text { Anthocyanin } \\
\text { (mg/100g F.W.) }\end{array}$} \\
\cline { 2 - 9 } & $\mathbf{2 0 1 3}$ & $\mathbf{2 0 1 4}$ & $\mathbf{2 0 1 3}$ & $\mathbf{2 0 1 4}$ & $\mathbf{2 0 1 3}$ & $\mathbf{2 0 1 4}$ & $\mathbf{2 0 1 3}$ & $\mathbf{2 0 1 4}$ \\
\hline Bacillus subtilis & 16.5 & 16.9 & 0.65 & 0.64 & 25.4 & 26.4 & 34.1 & 36.9 \\
T. harzianum (T1) & 16.4 & 16.7 & 0.67 & 0.66 & 24.5 & 25.3 & 33.8 & 34.9 \\
T. viride (T2) & 16.3 & 16.5 & 0.69 & 0.67 & 23.6 & 24.6 & 32.5 & 34.2 \\
Mixture of (T1+T2) & 16.7 & 17.2 & 0.63 & 0.62 & 26.5 & 27.7 & 35.4 & 38.1 \\
Blight stop & 16.9 & 17.3 & 0.63 & 0.61 & 26.8 & 28.4 & 37.2 & 39.5 \\
Micron sulphur & 16.1 & 16.2 & 0.71 & 0.69 & 22.7 & 23.5 & 31.7 & 33.1 \\
Control & 15.9 & 16.1 & 0.74 & 0.71 & 21.5 & 22.7 & 31.3 & 32.9 \\
\hline L.S.D at $\mathbf{0 . 0 5}$ & 0.4 & 0.3 & 0.03 & 0.02 & 1.4 & 1.3 & 2.4 & 2.1 \\
\hline
\end{tabular}


Table 5. Economical justification of the contribution of different vital bioagent treatments in raising vine productivity by reduced the powdery mildew disease compared with micron sulphur and control

\begin{tabular}{|c|c|c|c|c|c|c|c|}
\hline \multirow{2}{*}{ Per Feddan } & \multicolumn{7}{|c|}{ Season 2013} \\
\hline & $\begin{array}{l}\text { Bacillus } \\
\text { subtilis }\end{array}$ & $\begin{array}{l}\text { T. harzianum } \\
\text { (T1) }\end{array}$ & $\begin{array}{l}\text { T. viride } \\
\text { (T2) }\end{array}$ & $\begin{array}{l}\text { Mixture of } \\
(\mathrm{T} 1+\mathrm{T} 2)\end{array}$ & Blight stop & $\begin{array}{l}\text { Micron } \\
\text { sulphur }\end{array}$ & Control \\
\hline \multirow{10}{*}{ 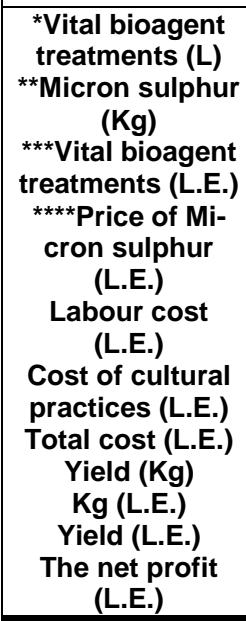 } & 24 & 24 & 24 & 48 & 24 & --- & --- \\
\hline & --- & --- & --- & --- & --- & 6.0 & --- \\
\hline & 840.0 & 840.0 & 840.0 & 1680.0 & 840.0 & --- & --- \\
\hline & --- & --- & --- & --- & --- & 150.0 & --- \\
\hline & 100.0 & 100.0 & 100.0 & 100.0 & 100.0 & 100.0 & --- \\
\hline & 8000 & 8000 & 8000 & 8000 & 8000 & 8000 & 8000 \\
\hline & 8940 & 8940 & 8940 & 9780 & 8940 & 8250 & 8000 \\
\hline & & $\begin{array}{l}18012.7 \\
3.00 \\
540381\end{array}$ & $\begin{array}{l}17919.4 \\
3.00\end{array}$ & $\begin{array}{l}20159.3 \\
3.00\end{array}$ & $\begin{array}{l}20345.9 \\
3.00\end{array}$ & $\begin{array}{c}16986.1 \\
3.00\end{array}$ & $\begin{array}{l}16519.4 \\
3.00\end{array}$ \\
\hline & 57118.0 & 54038.1 & 53758.1 & 60477.8 & 61037.8 & 50958.2 & 49558.2 \\
\hline & 48178.0 & 45098.1 & 44818.1 & 50697.8 & 52097.8 & 42708.2 & 41558.2 \\
\hline \multirow{2}{*}{ Per Feddan } & \multicolumn{7}{|c|}{ Sseason 2014} \\
\hline & B. subtilis & $\begin{array}{l}\text { T. harzianum } \\
\text { (T1) }\end{array}$ & $\begin{array}{l}\text { T. viride } \\
\text { (T2) }\end{array}$ & $\begin{array}{l}\text { Mixture of } \\
(\mathrm{T} 1+\mathrm{T} 2)\end{array}$ & Blight stop & $\begin{array}{l}\text { Micron } \\
\text { sulphur }\end{array}$ & Control \\
\hline \multirow{10}{*}{ 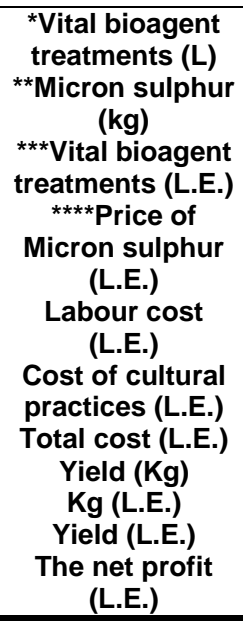 } & 24 & 24 & 24 & 48 & 24 & --- & --- \\
\hline & --- & --- & --- & --- & --- & 6.0 & --- \\
\hline & 840.0 & 840.0 & 840.0 & 1680.0 & 840.0 & --- & --- \\
\hline & --- & --- & --- & --- & --- & 150.0 & --- \\
\hline & 120.0 & 120.0 & 120.0 & 120.0 & 120.0 & 120.0 & --- \\
\hline & 8500 & 8500 & 8500 & 8500 & 8500 & 8500 & 8500 \\
\hline & 9460 & 9460 & 9460 & 10300 & 9460 & 8770 & 8500 \\
\hline & $\begin{array}{c}17079.4 \\
325\end{array}$ & $\begin{array}{c}16892.7 \\
3.25\end{array}$ & 16052.8 & $\begin{array}{c}18292.7 \\
325\end{array}$ & $\begin{array}{c}19226.0 \\
325\end{array}$ & 15212.8 & 14839.5 \\
\hline & 55508.0 & 54901.4 & 52171.5 & 59451.2 & 62484.4 & 49441.6 & 48228.3 \\
\hline & 46048.0 & 45441.4 & 42711.5 & 49151.2 & 53024.4 & 40671.6 & 39728.3 \\
\hline $\begin{array}{l}{ }^{*} \text { Vital bioagent } \\
\text { treatments }(\mathrm{L})\end{array}$ & \multicolumn{7}{|c|}{$6 \mathrm{LX} 4$ dates $=24 \mathrm{~L}$} \\
\hline $\begin{array}{l}{ }^{\star \star} \text { Micron sulphur } \\
(\mathrm{Kg})\end{array}$ & \multicolumn{7}{|c|}{$1.5 \mathrm{Kg} \mathrm{X} 4$ dates $=6 \mathrm{Kg}$} \\
\hline $\begin{array}{l}{ }^{\star \star \star} \text { Vital bioagent } \\
\text { treatments (L.E.) }\end{array}$ & \multicolumn{7}{|c|}{24 L X 35 L.E. = 840 L.E. } \\
\hline $\begin{array}{l}{ }^{\star * \star *} \text { Price of } \\
\text { Micron sulphur } \\
\text { (L.E.) }\end{array}$ & \multicolumn{7}{|c|}{$6 \mathrm{Kg} \mathrm{X} 25$ L.E. $=150.0$ L.E. } \\
\hline
\end{tabular}




\section{REFERANCES}

Abada, K.A. 2002. Fungi associated with fruit rots of fresh strawberry plantations and some trials of their control. Bulletin of Faculty of Agriculture, Cairo University. 53(2), 309-326.

AbdEl-Moity, T.H. 1981. Further studies on the biological control of white rot disease of onion. Ph. D. Thesis, Fac. Agric., Monoufia University, $135 \mathrm{pp}$.

AbdEl-Moity, T.H. and Shatla, M.N. 1981. Biological control of white rot disease of onion Sclerotium cepivorum by Trichoderma harzianum. Phytopathology Z., 100, 29- 35.

Abd El-Moity, T.H., Maisa, L.A.M. Atia, M.M., Aly, A.Z. and Tohamy, M.R.A. 2003. Biological control of some cucumber diseases under organic agriculture. 227- 236 Proc. IS on org. matter and substrates Ed A.F. AbouHadidActa. Hort., 608, ISHS 2003.

AbdEI-Moneim, Maisa, L. and Wafaa, S.M.A. 2006. Nutritional status of onion as affected by biological control of white rot disease. J. Agric. Sci., Mansoura Univ., 31(4), 2533-2549.

Ahmed, F.F. Abdel-Aziz, F.H. and Mohamed, M.A. 1991. Improving the quality of White Banati grapes treated with GA3 by some micro and macronutrients. 1. Effect of some micronutrients. Minia. J. Agric. Res. Develop., 13(2), 649-662.

Asaka, O. and Shoda, M. 1996. Biocontrol of Rhizoctonia solani damping off on tomato with $\mathrm{Ba}$ cillus subtilis RB14. Applied and Environmental Microbiology, 62, 4081 - 4085.

Association of Official Agriculture Chemists (A.O.AC.) 1985. Official Methods of Analysis. $12^{\text {th }}$ Ed.Published by Benjamin Franklin Station, Washington D.C., U.S.A.

Balode, A. 2010. Effect of tricodermin, biological product against Botrytis in horticultural crops. Acta Horticulture. 877, 1583-1588.

Benhamoud, W. and Chet, I. 1993. Hyphal interaction between Trichoderma and gold Cytochemistry of the mycoparasitic process. Phytopathology, 83, 1062-1071.

Bolar, J.P., Norelli, J.L., Wong, K.W., Hayes, C.K., Harman, Q.E. and Aldwinckle, H.S. 2000. Expression of endo chitinase from Trichoderma harzianumin transgenic apple increases resistance to apple scab and reduces vigor. Phytopathology, 90, 72- 77.

Braun, U. and Takamatsu, S. 2000. Phylogeny of Erysiphe, Microsphaera, Uncinula (Erysiphe) and Cystotheca, Podosphaera, Sphaerotheca
(Cystotheceae) inferred from rDNA ITS sequences - some taxonomic consequences. Schlechtendalia 4, 1-33.

Brian, P.W. and Hemming, H.G. 1945. Gliotoxina fungistatic metabolic product of Trichoderma viride. Ann. Appl. Biol., 32, 214-220.

Calonnec, P., Cartolaroa, C., Poupotb, S., Dubourdieub, D. and Darrietb, P. 2004. Effect of Uncinulanecator on the yield and quality of grapes (Vitisvinifera) and wine. Plant pathology. 53, 434-445.

Chang, Y.C., Baker, R., Kleifeld, O. and Chet, I. 1986. Increased growth of plants in the presence of the biological control agent Trichoderma harzianum, Plant Dis. 70, 145-148.

Chet, I., Inbar, J. and Hadar, I. 1997. Fungal antagonists and mycoparasites. In: The Mycota IV: Environmental and Microbial Relationships. Wicklow DT and Soderstorm B, eds. pp. 165184.

Constantinescu, F., Voshol, G. and Bloemberg, G. 2009. Mechanisms involved in biocontrol activity of $B$. subtilis B49b against Fusarium oxysporumf. sp. radicis-lycopersici. IOBC/WPRS Bulletin. 43, 113-116.

Cortesi, P., Mazzoleni, A. Pizzatti, C. and Milgroom, M.G. 2005. Genetic similarity of flag shoot and ascospore subpopulations of Erysiphe necatorin Italy. Applied Environmental Microbiology. 71, 788-791.

Crisp, P., Wicks, T.J., Troup, J. and Scott, E.S. 2006. Mode of action of milk in the control of grapevine powdery mildew. Australaian Plant Pathology, 35, 487-493.

David, M.G., Robert, C.S., Roger, C.P., Wayne, F.W. and Richard, M.D. 2001. Effects of powdery mildew on vine growth, yield, and quality of concord grapes. Plant Dis. 2001; 85,137-140.

Delye, C.; Laigret, F. and Corio-Costet, M.F. 1997. RAPD analysis provides insight into the biology and epidemiology of Uncinula necator. Phytopathology. 87, 670-677.

Dowson, W.J. 1957. Plant disease due to bacteria Second Ed., Cambridge University Press, London, 23 p.

Ellis, S.D., Boehm, M.J. and Mitchell, T.K. 2008. Fungal and fungal-like diseases of plants: Ohio State University Extension pp. 401.07.

El-Rafai, Ilham, M., Susan, M.W. and Omaima, A.A. 2003. Biocontrol of some tomato diseases using some antagonistic microorganisms. Pakistan Tournal of Biological Science, 6(4), 399406. 
Emmett, R.W., Magarey, P.A. and Wicks, T.J. Hitch, C. 2003a. Strategic use of sulphur in disease and pest management programs for dried vine fruit production. Final report to Horticulture Australia, Project DG01002, Department of Primary Industries, Victoria. 2 p.

Emmett, R.W., Magarey, P.A. and Wicks, T.J. Hitch C. 2003b. Strategic use of sulphur in integrated pest and disease management programs for grapevines. Final report to the Grape and Wine Research and Development Corporation, Project DAV 98/1, Department of Primary Industries, Victoria. 1 p.

EPA 2009. Pesticides. http://www.epa.gov/pesticides/a-z/index.htm.

Fawzi, F., Kamel, A. and Mougi M. 1984. Effect of pruning severity on fertility of buds and dynamics of bunch and wood ripening in Thompson seedless grapevines. Agric. Res.Egypt, 62(3), 101-108.

Fawzi, M.I.F., Shahin, M.F.M. and Kandil, E.A. 2010. Effect of bud load on bud behavior, yield, bunch characteristics and some biochemical contents of the cane of crimson seedless grapevines. Journal of American Science. 6(12), 187-194.

Ferreira, J.H.S., Matthee, F.N. and Thomas, A.C. 1991. Biological control of Eutypalota on grapevine by an antagonistic strain of Bacillus subtilis. Phtopathology, 81, 283- 287.

Gadoury, D.M., Seem, R.C., Pearson, R.C., Wilcox, W.F. and Dunst, R.M. 2001. Effects of powdery mildew on vine growth, yield and quality of Concord grapes. Plant Dis. 85, 137-140.

Geza, H., Parsons, G.F. and Mattick, L.R. 1984. Physiological and biochemical events during development and maturation of grape berries. A.M.J. Enol.Vitic. 35(4), 220-227.

Govindappa, M., Lokesh, S., Naikand, V.R. and Raju, S.G. 2011. Induction of systemic resistance and management of sun flower Macrophomina phaseolina root-rot disease by biocontrol agents. Archives of Phytopathology and Plant Protection, 43(1/3), 26-40.

Grosch, R. and Grote, S. 1998. Suppression of Phytophthora nicotianae by application of Bacillus subtilis in closed soil less culture of tomato plants. Gartenbauwissensschaft, 63(3), 103109.

Hafez, E.E., Balbaa, M.M., Kabeil S.S., EISaadani, M.A. and Ahmed, S.A. 2012. Molecular studies on the biocontrol effect of Trichoderma viride and Bacillus subtilis on Fusarium oxysporum and Rhizoctonia solani infected tomato plants. World Applied Sciences J., 19(1), 8999.

Hajjeh, H., Miazzi, M. De Guido, M.A. and Faretra, F. 2005. Specific SCAR primers for the flag shoot and ascospore biotypes of the grape powdery mildew Erysiphe necator. Journal of Plant Pathology 87, 71-74.

Harman, G.E. 2006. Overview of mechanisms of uses of Trichoderma spp. Phytopathology, 96, 190-194.

Hayes, C.K. 1992. Improvement of Trichoderma and Gliocladium by genetic manipulation, pp. 227- 266. In Biological control of plant diseases progress and challenges for the future. E.C.; G.C. Papavizas and R.J. Cook (Eds) Plenun Press, New York and London published in cooperation with NATO Scientific Affairs Division, $462 \mathrm{p}$.

Hernandez, S.M., Castillo, F.D., Morales, G. Saldivar, R.H. and Aguilar, C.N. 2011. Biocontrol of soil fungi in tomato with microencapsulates containing Bacillus subtilis. American Journal of Agric. and Biological Sciences, 6 (2):189195.

Horsfall, J.G. and Barratt, R.W. 1945. An improved grading system for measuring plant diseases. Phytopathology, 35, 655.

Husia, C.L., Luh, B.S. and Chichester, C.D. 1965. Anthocyanin in free stone peach. J. Food Science, 30, 5-12.

Hussein, M.A.M., Hassan, M.H.A., Allam, A.D.A. and Abo Elyousr, K.A.M. 2007. Management of Stemphylium Blight of onion by using biological agents and resistance inducers. Egypt. J. Phytopathol., 35((1), 49- 60.

Intana, W., Yenjit, P., Suwanno, T., Sattaskulchai, S., Suwanno, M. and Chamswarng, C. 2008. Efficacy of antifungal metabolites of Bacillus spp. for controlling tomato damping off caused by Pythium aphanidermatum. Walailak. J. Sci. \& Tech, 5(1), 29-38.

Jailloux, F., Willocquet, L., Chapuisand, L. and roidef, G.F 1999. Effect of weather factors on the release of ascospores of Uncinula necator, the cause of grape powdery mildew, in the Bordeaux region. Canadian Journal of Botany 77, 1044-1051.

Karlidag, H., Esitken, A., Yildirim, E., Donmez, M.F. and Turan, M. 2012. Effects of plant growth promoting bacteria on yield, growth, leaf water content, membrane permeability, and ionic composition of strawberry under saline conditions. J. of Plant Nutrition, 34(1), 34-45.

Kloepper, J.W., Choongmim, R.Y.U. and Zhang, S.A. 2004. Induced systemic resistance and 
promotion of plant growth by Bacillus spp. Phytopathology, 94(11), 1259-1266.

Latha, P., Ragupathi, A.N.T. and Samiyappan, R.V. 2009. Antimicrobial activity of plant extracts and induction of systemic resistance in tomato plants by mixtures of PGPR strains and Zimmu leaf extract against Alternaria solani. Biological Control. 50(2), 85-93.

Matei, G.M. and Matei, S. 2008. Research on isolation, characterization and testing the interaction between Trichoderma harzianum and Botrytis cinerea for biological control of gray mold in strawberry. Horticultura, 51, 653-657.

Miazzi, M., Hajjeh, H. and Faretra, F. 2003. Observations on the population biology of the grape powdery mildew fungus Uncinula necator. Journal of Plant Pathology 85, 123-129.

Monteiro, S., Grondona, L.M. Llobell, I. and Monte, A. 2011. In vitro antifungal activity of Trichoderma harzianum, T. longibrachiatum, $T$. asperellum and $T$. atroviride against Botrytis cinerea to strawberry. Bulletin OILB/SROP, 25(10), 253-256.

Osman, M.S., Agwa, H.E., El-shanshoury, A.R. and El-halouish, Y.H. 2001. Biocontrol of sugar beet leaf spot disease by Streptomyces anulous, $S$. chromofuscus, $S$. alsaduncusand Trichoderma viride and their influence on the plant sugar content. El-Azher J. Microbial, 51, 109-128.

Peros, G.P., Troulet, C., Guerriero, M., Romiti, C.M. and Notteghem, J.L. 2005. Genetic variation and population structure of the grape powdery mildew fungus, Erysiphe necator, in southern France. European Journal of Plant Pathology 113, 407- 416.

Possingham, J. 2002. Dusting sulphur: the forgotten chemical of Australian viticulture. The Australian and New Zealand Grape grower \& Winemaker, April, 459, 15-16.

Robinson, L.M., Jeger, J. and Xiangming, P. 2009. Management of strawberry gray mould using mixtures of biocontrol agents with different mechanisms of action. Biocontrol Science and Technology. 19, 1051-1065.

Rumbolz, J., Kassemeyer, H.H., Steinmetz, V. Deising, H.B.K. Mendgen, D., Mathys, S., Wirth, L. and Guggenheim, R. 2000. Differentiation of infection structures of the powdery mildew fungus Uncinula necator and adhesion to the host cuticle. Canadian Journal of Botany 78, 409-421.

Ryder, M.H., Yan, Z.H., Terrace, T.E., Rovira, A.D., Tang, W., Correll, R.L., Yan, Z. and
Tang, W. 1999. Uses of strains of Bacillus isolated in China to suppress take all and Rhizoctonia root rot and promote seedling growth of glasshouse grown wheat in Australian soil. Soil Biology and Biochemistry, 31(1), 19- 29.

Saleh, M.M.S., Ashour, N.E., El-Sheikh, S.L. and El-Naggar, M.A.A. 2007. Foliar sprays of potassium dihydrogen phosphate and their impact on yield, fruit quality and controlling powdery mildew disease of Thompson seedless grapevines. J. Agraic. Environs. Sci., 2(2), 133-140.

Sankar, P. and Jeyarajan, R. 1996. Biological control of sesame root rots by seed treatment with Trichoderma spp. and Bacillus subtilis. Indian Journal of Mycology and Plant Pathology, 26(2), 217- 220.

Sharifi, T.A. and Ramezani, M. 2003. Biological control of Fusarium oxysporum, the causal agent of onion wilt by antagonistic bacteria. Common Agric Appl. Biol. Sci. 68, 543-547.

Singh, V., Singh, P.N., Yadav, R.L., Awasthi, S.K., Singh, R.K. and Duttamajumder, S.K. 2010. Increasing the efficacy of Trichoderma harzianum for nutrient uptake and control of red rot in sugarcane. J. of Horticulture and Forestry. Vol. 2(4), 66-71.

Sivan, A. and Chet, I. 1992. Integrated control of Medica on growth and interaction between a range of soil borne glasshouse pathogens and antagonistic fungi. Phytopathology, 82, 127142.

Snedcor, G.W. and Cochran, W.G. 1984. Statistical Methods $7^{\text {th }}$ ed. The lowa state Univ. Press, Ames, lowa, USA.

Tourky, M.N., El-Shahat, S.S. and Rizk, M.H. 1995. Evaluation of some new grape cultivars in relation to growth, yield, berry quality and storage life. J. Agric. Sci., Masoura Univ., 20(12), 5153-5167.

Tronsmo, A., Klemsdal, S.S., Hayes, C.K., Lorito, M. and Harman, G.F. 1993. The role of hydrolytic enzymes produced by Trichoderma harzianum in biological control of plant diseases. Found for Biochem and Indust. Ferme. Nuation Res., Helsiniki., 8, 159-169.

Wolk, M. and Sorkar, S. 1994. Antagonism In vivo of Bacillus spp. against Rhizocotonia solani and Pythium spp. Angeiger fur Schandingskundey PF Lanzenchutz, Umweltschutz, 67, 1-5.

Ziedan, E.H., Moataza, M.S. and Eman, F.S. 2005. Biological control of grapevine root- rots by antagonistic microorganisms. African Journal of Mycology and Biotechnology. 13(3), 19-36. 